\title{
Correlation between fms-Like Tyrosine Kinase-1 (sFlt-1) Cell-Free Messenger RNA Expression and fms-Like Tyrosine Kinase-1 (sFlt-1) Protein Level in Severe Preeclampsia and Normal Pregnancy
}

\author{
Jeffry Iman Gurnadi, ${ }^{1}$ Johanes Cornelius Mose, ${ }^{1}$ Budi Handono, ${ }^{1}$ Prima Nanda Fauziah, ${ }^{2}$ \\ Akhmad Yogi Pramatirta ${ }^{1}$ \begin{abstract}
General Hospital
\end{abstract} \\ ${ }^{1}$ Department of Obstetrics and Gynecology, Faculty of Medicine, Universitas Padjadjaran-Dr. Hasan Sadikin \\ ${ }^{2}$ Department of Biology, School of Life Sciences and Technology, Bandung Institute of Technology, Indonesia
}

\begin{abstract}
Objective: To analyze sFlt-1 and sFlt-1 mRNA levels in severe preeclampsia and normal pregnancy, and the correlation between both in occurrence of severe preeclampsia.

Methods: This is a cross-sectional analytic observational study involving 18 subjects with severe preeclampsia and 19 subjects with normal pregnancy as controls who met inclusion and exclusion criteria. Levels of sFlt-1 and sFlt-1 mRNA were measured with ELISA and RT PCR. Statistical analysis was performed with Chi square test, Fisher's exact test, T-test, Mann-Whitney test, and Spearman's rank correlation test.

Results: This study showed no significant difference $(p>0.05)$ in the characteristics of maternal age, gestational age, and parity in both study groups. Mean level of sFlt-1 mRNA in severe preeclampsia was higher $(6.3404$ $\mathrm{pg} / \mathrm{mL}$ ) compared to its level in normal pregnancy $(5.9701 \mathrm{pg} / \mathrm{mL})$. There was an insignificant $(p>0.05)$ positive correlation between sFlt-1 mRNA and sFlt-1 levels in normal pregnancy, and an insignificant $(p>0.05)$ negative correlation between both levels in severe preeclampsia.

Conclusions: sFlt-1 mRNA levels in severe preeclampsia are higher than its level in normal pregnancy. There is no correlation between sFlt-1 mRNA Received: level and sFLt-1 protein level in severe preeclampsia. There is an insignificant May 6, 2015 positive correlation between sFlt-1 mRNA and sFlt-1 levels in normal pregnancy, and an insignificant negative correlation between both levels in

Revised: severe preeclampsia.
\end{abstract}

August 15, 2015

Accepted:

August 28, 2015

Keywords: Normal pregnancy, severe preeclampsia, sFlt-1 mRNA

IJIHS. $2015 ; 3(2): 66-71$

\section{Introduction}

Gestational hypertension is one of the most common complications in pregnancy, labor, or postpartum which increases both maternal and perinatal morbidity and mortality. Severe preeclampsia is a pregnancy specific syndrome characterized by systolic blood pressure of $\geq 160 \mathrm{mmHg}$ and a diastolic blood pressure of $\geq 110 \mathrm{mmHg}$, with

\footnotetext{
Correspondence:

Jeffry Iman Gurnadi, Department of Obstetrics and Gynecology, Faculty of Medicine, Universitas Padjadjaran-Dr. Hasan Sadikin General Hospital Jl. Pasteur No. 38, Bandung, Indonesia e-mail: jeffryiman@gmail.com
}

qualitative proteinuria of $>+1$ or $0.3 \mathrm{~g} / 24$ hrs. ${ }^{1,2}$ World Health Organization (WHO) in 2006 reported that gestational hypertension contributes $16 \%$ of 3,201 mortalities caused by pregnancy. ${ }^{3}$ According to data from the National Center for Health Statistics in USA, gestational hypertension occurs in 150,000 women or $3.7 \%$ of all pregnancies. ${ }^{1}$ National Vital Statistics recorded that incidence of preeclampsia increases by $40 \%{ }^{4}$ A survey done by the Indonesian government in 2007 found that preeclampsia/eclampsia has contributed to about $24 \%$ maternal mortality in Indonesia, making it the second cause of maternal death in Indonesia. In Dr. Hasan Sadikin General Hospital, Bandung, preeclampsia was reported 
in $3.5 \%$ cases and eclampsia in $2.8 \%$ cases in 2006 , while in 2008-2010 preeclampsia was reported in $4.0-10.4 \%$ cases and eclampsia in $2.3-4.3 \%$ cases. $^{5,6}$

A hypothesis has been suggested that the underlying mechanism of preeclampsia involves genetic factors, immunologic factors, vascular disease, and conditions in which excessive trophoblast were unable to invade the spiral artery in the early phase of the first trimester. These cause the spiral artery to dilate inadequately and disturbance in endothelial and muscular wall of blood vessel, leaving the blood vessel smaller in diameter, that leads to diminished perfusion and placental ischemia. ${ }^{3}$ Moreover, oxidative stress, free radicals, endothelial dysfunction, thrombocyte aggregation and plugging, as well as hypoxia will follow, rendering damage to maternal organs. Failure of remodeling process of spiral artery impedes adequate response to increase the need for perfusion as pregnancy advances leading to diminished uteroplacental perfusion and imbalance of pro- and anti-angiogenic factors which further worsens placental ischemia and renders the whole endothelium to damage. ${ }^{7,8}$

Placental ischemia causes the concentration of placental soluble FMS-like tyrosine kinase-1 (sFlt-1) to elevate. sFlt-1 is an antiangiogenic factor that is produced by hypoxic placental cells. $^{9-12}$ sFlt-1 is believed to play a role as an etiologic factor of endothelial damage in preeclampsia. ${ }^{3-15}$ Elevated concentration of sFlt-1 will modify endothelial integrity of blood vessel, causing a blood-brain-barrier damage which leads to hepatic and brain edema as well as hypertension and proteinuria encountered in preeclamptic patients. ${ }^{9}$ sFlt-1 can also be found in normal pregnancy after the $35^{\text {th }}$. week. $^{9}$ sFlt- 1 found in preeclamptic white people is about $4,383 \pm 657 \mathrm{pg} / \mathrm{mL}$, while in normal pregnancy it is $1,643 \pm 940 \mathrm{pg} / \mathrm{mL}^{13-}$ ${ }^{14}$ Elevation of sFlt-1 concentration was found weeks before clinical onset of hypertension and proteinuria. Measurements of sFlt-1 are necessary to asses the dynamics in serum values. It is therefore used as the predictive marker for future pregnancy outcome and risk of developing preeclampsia. ${ }^{11,12}$

Table 1 Characteristics of Study Subjects by Age, Parity, and Gestational

\begin{tabular}{|c|c|c|c|}
\hline \multicolumn{4}{|c|}{ Group } \\
\hline Characteristics & $\begin{array}{c}\text { Preeclampsia } \\
\qquad(n=18)\end{array}$ & $\begin{array}{c}\text { Normal } \\
(n=19)\end{array}$ & p value \\
\hline \multicolumn{4}{|l|}{ Age (yrs. old) } \\
\hline$<20$ & 4 & 1 & \\
\hline $21-34$ & 11 & 15 & 0.831 \\
\hline $35>$ & 3 & 3 & \\
\hline \multicolumn{4}{|l|}{ Parity } \\
\hline Primi & 7 & 6 & 0.195 \\
\hline Multi & 11 & 13 & \\
\hline \multicolumn{4}{|l|}{ Gestational age (weeks) } \\
\hline 37 & 8 & 10 & $0.221^{*}$ \\
\hline 38 & 6 & 2 & \\
\hline 39 & 4 & 7 & \\
\hline Mean $( \pm$ SD $)$ & $37.8(0.8)$ & $32.4(5.4)$ & \\
\hline Median & 38 & 37 & \\
\hline Range & $37-39$ & $37-39$ & \\
\hline
\end{tabular}

Note: $p$ value for maternal age and parity is analyzed with Chi square test; $p$ value for gestational age is analyzed with T-test*. 
Table 2 Comparison of sFlt-1 Level and Log sFlt-1 mRNA in Severe Preeclampsia and Normal Pregnancy with Shapiro-Wilk

\begin{tabular}{lcccc}
\hline \multirow{2}{*}{ Characteristics } & $\begin{array}{c}\text { Preeclampsia } \\
(\mathbf{n = 1 8})\end{array}$ & $\begin{array}{c}\text { Normal } \\
(\mathbf{n = 1 9 )}\end{array}$ & T test & p Value \\
\cline { 2 - 3 } sFlt-1 (pg/dL) & & & & \\
Mean (SD) & $18,086(8,821.45)$ & $7,277.36(4,673.01)$ & $<0.001$ \\
Range & $1,430.5-28,540.5$ & $1,657.6-18,859.6$ & 4.693 & \\
Log sFlt-1 mRNA & $135.0(310.3)$ & $441.9(381.9)$ & & \\
Mean (SD) & $10-1,361$ & $54-1,156$ & 1.982 & $<0.001$ \\
Range & & & & \\
\hline
\end{tabular}

Vascular endothelial growth factor (VEGF) has two signal receptors; VEGF-1 receptor (VEGFR-1) and VEGF-2 receptor (VEGFR-2), which is also known as fms-like tyrosine kinase-1 (Flt-1). Soluble form of VEGFR-1 is called sFlt-1, an alternative fragment of messenger RNA (mRNA). mRNA is a part of RNA which contains information to protein synthesis in ribosome.

Within the last few years, researchers have been interested in cell-free fetal DNA (cff DNA) upon the evidence that fetal blood is mixed within maternal blood, which was proven by documentation of fetal DNA in maternal circulation. The term cff DNA is used to describe fetal DNA identified in maternal circulation (fetal genetic material in maternal circulation). ${ }^{16,17}$ This material is also found in normal pregnancy in various levels associated with maternal and fetal conditions. ${ }^{3}$ Placenta is believed to hold a very important role in the leakage of fetal genetic material into the maternal circulation. ${ }^{17}$ Cell-free fetal DNA is thought to originate from trophoblastic apoptosis which is spilled into the maternal circulation. Therefore, cell-free fetal mRNA (cff mRNA) can be used to identify the expressed protein. ${ }^{13-20}$

sFlt-1 is a protein which is mostly produced in placenta and an expression of sFlt-1 mRNA. This study aimed to identify the levels of sFlt-1 expressed by cff mRNA in women with preeclampsia and its correlation with sFlt-1 in preeclamptic maternal serum. The result is expected to give better understanding in mechanism of preeclampsia.

\section{Methods}

This was an observational analytic crosssectional study. Pregnant women with singleton living intrauterine fetus with a gestational age of $\geq 37$ weeks according to the last day of menstrual period and medical record presented to Dr. Hasan Sadikin General Hospital, Cibabat General Hospital, and Astana Anyar Hospital, Bandung, Indonesia from January to June 2011 were included in this study. Those with normal blood pressure and negative proteinuria were included in control group (normal pregnancy) while those who meet the criteria of preeclampsia with positive proteinuria were included in

Table 3 Correlation of sFlt-1/PIGF Ratio in Severe Preeclampsia and Normal Pregnancy

\begin{tabular}{ccccc}
\hline \multirow{2}{*}{ Correlation } & \multicolumn{2}{c}{$\begin{array}{c}\text { Severe Preeclampsia } \\
\text { (n=18) }\end{array}$} & \multicolumn{2}{c}{$\begin{array}{c}\text { Normal } \\
(\mathbf{n = 1 9 )}\end{array}$} \\
\cline { 2 - 5 } & $\mathbf{R}$ & p Value & $\mathbf{R}$ & p Value \\
\hline Log sFlt-1 x log mRNA & 0.266 & 0.287 & -0.061 & 0.803 \\
\hline Note: $r=$ Pearson correlation coefficient; two tall test" & & &
\end{tabular}




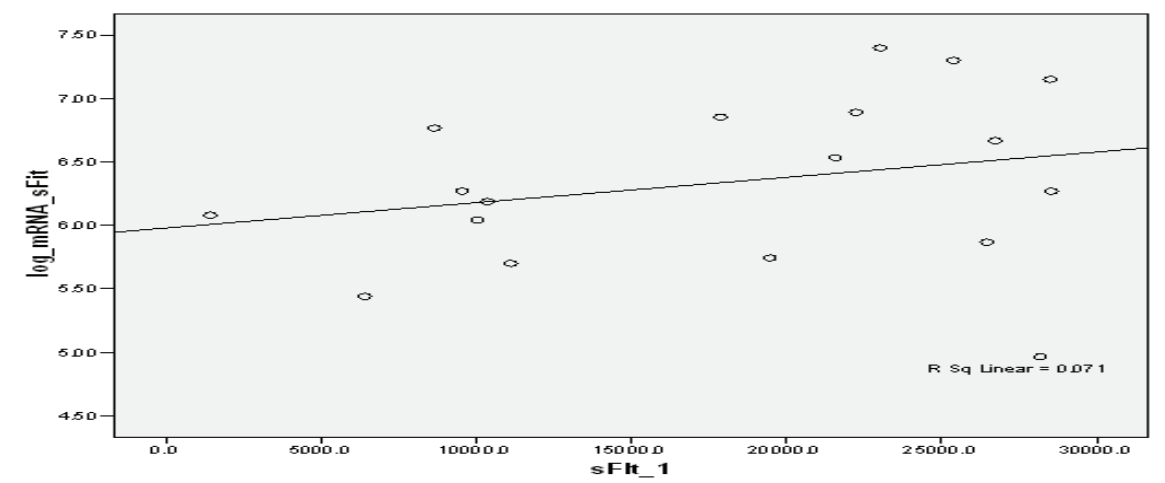

Fig. 1 Correlation between Variables sFlt-1 and Log sFlt-1 mRNA in Normal Pregnancy

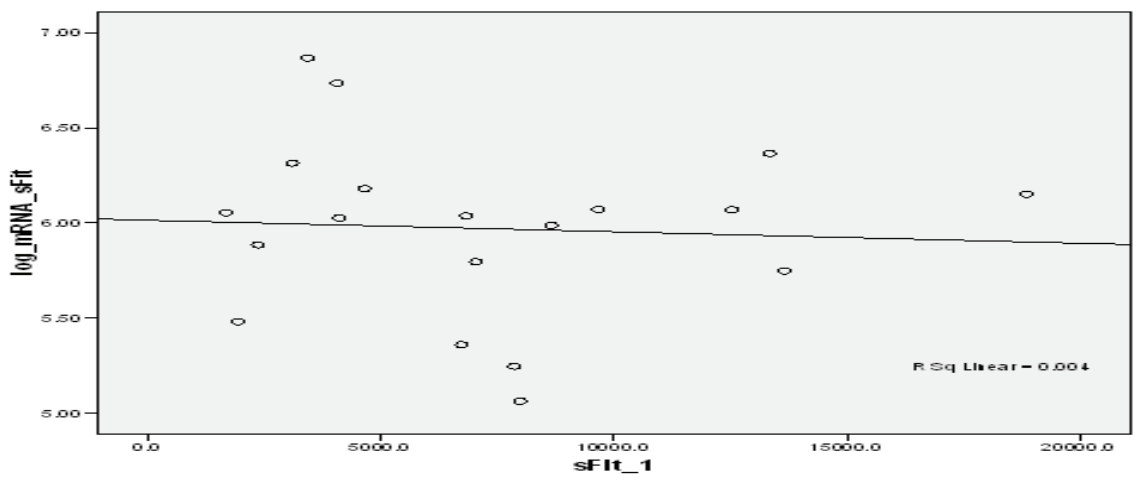

Fig. 2 Correlation between Variables sFlt-1 and Log sFlt-1 mRNA in Severe Preeclampsia

the preeclampsia group. Fetal congenital malformations confirmed with USG, mother having infection or history of chronic diseases (renal, cardiac, hypertension, diabetes mellitus, hypothyroidism, peptic ulcer, etc) and who smokes or drink alcohol, as well as pregnancy with fetal growth restriction were excluded. Subjects were taken consecutively, consisting of 18 preeclamptic patients and 19 women with normal pregnancy as the control group.

Blood pressure was measured at the Department of Obstetrics and Gynecology clinic while the protein level in urine was measured at the Clinical Pathology Laboratory of Dr. Hasan Sadikin Hospital, Bandung to diagnose preeclamptic pregnancy and normal pregnancy. Blood sample was withdrawn and then kept in $-20{ }^{\circ} \mathrm{C}$ temperature. Sample was stored in Prodia Laboratory in Bandung and treated in Prodia laboratory in Jakarta afterwards. Levels of sFlt- 1 were measured with Quantikine ${ }^{\circledR}$ ELISA, while levels of sFlt1 cff mRNA were examined with QIAamp MinElute Virus column to separate DNA from RNA and TagMan PCR analysis to define protein type.

Categorical data were analyzed by using Chi square or Fisher's exact test when the expected value was less than 5. Normallydistributed data were compared with T-test, while the not-normally-distributed ones were analyzed with Mann-Whitney test. Ratio of proteins was analyzed with Spearman"s rank correlation test. Data analysis was performed with SPSS for Windows version 15.0, with $85 \%$ confidence interval and $\mathrm{p}$ value of $<0.05$. Written informed consent was obtained from all participants. The Ethical Reviews Boards of the Health Research Ethics Committee, 
Faculty of Medicine, Universitas PadjadjaranDr. Hasan Sadikin General Hospital, Indonesia, approved this study.

\section{Results}

Characteristics of age, parity, and gestational age were compared for homogeneity. There were no significant difference in maternal age $(\mathrm{p}=0.831, \mathrm{p}>0.05)$, parity $(\mathrm{p}=0.195, \mathrm{p}>0.05)$, and gestational age $(p=0.221, p>0.05)$ between the two groups. Characteristics of subjects were therefore homogenous (Table 1).

sFlt-1 level was significantly higher in severe preeclampsia group compared to its level in normal pregnancy $(p<0.001)$, while expression of sFlt-1 mRNA was also significantly lower in normal pregnancy compared to severe preeclampsia $(p=0.028)$ (Table 2).

A positive correlation between level of sFlt1 and sFlt-1 mRNA in normal pregnancy, in which the higher the sFlt-1 level the higher the expression of sFlt-1 mRNA was seen (Fig.1). However, this correlation was not significant $(\mathrm{p}=0.287)$. No correlation of sFlt-1 and sFlt-1 mRNA in severe preeclampsia was observed ( $\mathrm{p}=0.803$ ) (Fig. 2).

\section{Discussion}

It has been reported that younger age, primigravida, and gestational age are all confounding factors that cause preeclampsia. ${ }^{1-3}$ Incidence of preeclampsia is higher in young age and nulipara, while it also increases with advanced maternal age due to increased risk of chronic hypertension, particularly in age older than 35 years old. ${ }^{3}$ Characteristics of subjects in this study were homogenous in maternal age, gestational age, and parity.

Levels of sFlt- 1 in severe preeclampsia were significantly higher when compared to normal pregnancy. Referring to the theory of preeclampsia and its pathophysiology, which is imbalance of pro- and anti-angiogenic factor, correlation between sFlt-1 and sFlt-1 mRNA concentration is important to be noted. ${ }^{3}$ It has been hypothesized that sFlt-1 concentration would continue to elevate as placental hypoxia advances and is associated with clinical manifestation of preeclampsia: elevated blood pressure and proteinuria. sFlt-1 elevation in circulation can be caused by increased activity within cellular level in producing sFlt1 protein.
Elevated cff mRNA refers to elevated sFlt1 protein in maternal serum. Particularly for mRNA in maternal serum, its elevation is detected both severe preeclampsia and normal pregnancy. Referring to the theory of placental leakage, this study proves detection of free cff mRNA in maternal circulation, specifically in serum. Hypoxia of trophoblasts leads to trophoblastic cell death or apoptosis, which will rupture then release substances within the cell into uteroplacental circulation, and be detected in maternal serum. . $^{17,18}$

Elevation of sFlt-1 can be detected not only in preeclamptic women but also in women without clinical manifestations of preeclampsia. Theoretically, when this happens, the woman will have preeclampsia in the next few weeks,. ${ }^{19}$ The administration of parenteral sFlt-1 on animals had been documented to elevate blood pressure, proteinuria, and glomerular endotheliosis, which are similar to clinical manifestations of preeclampsia. $^{3,18}$

sFlt-1 and sFlt-1 mRNA had an insignificant correlation in normal pregnancy $(p=0.287)$, as well as in severe preeclampsia ( $p=0.803)$ (Fig. 1). The log transformation was used to make data more interpretable and correlation clear. Results can be explained with a theory that sFlt- 1 is produced by ischemic placenta, in which the more extended the ischemic degrees, the more elevated the level of sFlt-1 in maternal serum. ${ }^{9,19,20}$ The correlation was not significant in normal pregnancy, consistent with the theory of placental leakage, which extends as pregnancy advances. However, the opposite result was found for the group with severe preeclampsia, in which the correlation between sFlt-1 and sFlt-1 mRNA was not significant.

This insignificant correlation between the sFlt- 1 and sFlt- 1 mRNA can be explained by the fact that etiology of preeclampsia is multifactorial, as explained by, among others, Aggarwal et al. ${ }^{9}$ It is found that not only elevation of sFlt-1 but also another factors of its balance is also needed including PIGF, or another factor which is synergistic with sFlt1 (antiangiogenic) such as endothelin-1 (ET1 ), a potent peptide causing vasoconstriction produced by endothelium and muscles of blood vessel. $3,9,20$

sFlt-1 mRNA levels in severe preeclampsia were higher than in normal pregnancy whereas sFlt-1 mRNA level was not associated with sFLt-1 protein level in both normal pregnancy and severe preeclampsia. Further study measuring sFlt-1 mRNA expression in 
fetal umbilical cord and placenta to compare clinical manifestations in larger number of samples is encouraged. In conclusions, sFlt1 mRNA levels in severe preeclampsia were higher than its level in normal pregnancy whereas sFlt- 1 mRNA level was not associated with sFLt-1 protein level in both normal pregnancy and severe preeclampsia.

\section{References}

1. Cunningham FG, Norman FG, Kenneth JL, Larry CG, John CH, Katharine DW. Williams Obstetrics. $22^{\text {nd }}$ ed. New York: Williams and Wilkins; 2005.

2. Hallak M. Hypertension in Pregnancy In: James DK, Weiner CP, Gonik B, eds. High risk pregnancy management option. $2^{\text {nd }}$ ed. London: WB Saunders; 2009. p. 639-63.

3. Cunningham FG, Leveno KJ, Bloom SL, Hauth JC, Rause DJ, Spancy CY. Wiliams obstetrics. $23^{\text {rd }}$ ed. New York: Mc Graw Hill; 2010. p. 710-10.

4. Ventura SJMJ, Curtin SC, Menacker F, Hamilton BE. Births: final data for 1999 National Vital Statistics Reports. 2001.

5. Karnaen K, Krisnadi SR. Perbedaan kadar vascular matrix metalloproteinase (MMP)2, MMP(9) dan transforming growth factor (TGF) $\beta 1$ pada penderita preeklamsi dan kehamilan normal serta rasio vascular matrix metalloproteinase (MMP)2, MMP9 terhadap transforming growth factor (TGF) $\beta 1$ pada preeklamsi berat (Dissertation). Bandung: Universitas Padjadjaran; 2009.

6. Pusat Data dan Informasi Kementerian Kesehatan Republik Indonesia. Hari Ibu: Situasi Kesehatan Ibu. [cited 2014 December 12]. Available from: www.depkes.go.id/download. php?file.../infodatin/infodatin-ibu.pdf.

7. Robert JM, Pregnancy-related hypertension. In: Creasy R, Iams J, Eds. Maternal fetal medicine principle and practice. $5^{\text {th }}$ ed. Philadelphia: WB Saunders; 2004. p. 859-80.

8. Park M, Brewster UC. Management of preeclampsia. Hosp Phys. 2007;43(11):25-32.

9. Aggarwal PK, Chandel N, Jain V, Jha V. The relationship between circulating endothelin-1, soluble fms-like tyrosine kinase- 1 and soluble endoglin in preeclampsia. J Hum Hypertens. 2012;26(4):236-41.

10. Kendall RL, Thomas KA. Inhibition of vascular endothelial cell growth factor activity by an endogenously encoded soluble receptor. Proc Natl Acad Sci U S A. 1993;90(22):10705-9.
11. Levine RJ, Qian C, Maynard SE, Yu KF, Epstein FH, Karumanchi SA. Serum sFlt1 concentration during preeclampsia and mid trimester blood pressure in healthy nulliparous women. Am J Obstet Gynecol. 2006;194(4):1034-41.

12. Purwosunu Y, Sekizawa A, Farina A, Wibowo $\mathrm{N}$, Koide K, Okazaki S, et al. Evaluation of physiological alterations of placenta through analysis of cell free messenger ribonucleic acid concentrations of angiogenic factor. Am J Obstet Gynecol. 2008;198(1):124. el-7.

13. Thana NG, Romerob R, Hillermannd R, Cozzie V, Nief G, Huppertzg B. Prediction of preeclampsia -a workshop report. Placenta. 2008;29(Suppl A):S83-5.

14. Mutter WP, Karumanchi SA. Molecular mechanisms of preeclampsia. Microvasc Res. 2008;75(1):1-8.

15. Isken 0 , Maquat LE. Quality control of eukaryotic mrna: safeguarding cells from abnormal mrna function. Genes Dev. 2007; 21(15):1833-56.

16. Purwosunu Y1, Sekizawa A, Okazaki S, Farina A, Wibowo N, Nakamura M, et al. Prediction of preeclampsia by analysis of cell-free messenger rna in maternal plasma. Am J Obstet Gynecol. 2009;200(4):386. e1-7.

17. Grill S, Rusterholz C, Zanetti-Dällenbach R, Tercanli S, Holzgreve W, Hahn S, et al. Potential markers of preeclampsia-a review. Reprod Biol Endocrinol. 2009;14(7):70.

18. Kopcow HD, Karumanchi SA. Angiogenic factors and natural killer (NK) cells in the pathogenesis of preeclampsia. J Reprod Immunol. 2007; 76(1-2):23-9.

19. Yu Chen. Novel angiogenic factors for predicting preeclampsia: sFlt-1, PlGF, and soluble endoglin. Open Clin Chemistry J. 2009; 2(1):1-6.

20. Creasy RK, Resnik R. Maternal fetal medicine principles and practice. 6th ed. London: WB Sanders 2009. 